УАК 171

DOI: $10.26565 / 2226-0994-2020-62-18$

\title{
Олександра Стебельська
}

\section{АО ПИТАННЯ ПРО ПРИРОАУ СОВІСТІ. КРИЗА СОВІСТІ}

Ця стаття присвячена осмисленню природи совісті, іiі сутнісних проявів та особливостей. Совість є «серцем» морального життя Аюдини. В актах совісті віАбувається активізація та акумуляція внутрішніх енергій Аюдини, які допомагають Аюдині перебувати в повноцінному взаємозв'язку зі світом і проводити грунтовну оцінку як власних дій, так і дій Інших. Тому феномен совісті нерозривно пов'язаний зі свободою Аюдини та іiі зусилАями самоздійснення, з ії прагненнями віднайти власний внутрішній голос. Попри свою інтимність, совість ніколи не замикається в межах індивіАуального буття, а володіє безумовною віАкритістю світові, є гострим усвідомленням відповіАальності за вчинені нами Аіi. Совість є свіАченням того, що на глибинному рівні ми вкорінені в єАиній Реальності та нерозривно з нею пов'язані. У результаті критичного аналізу стверджується, що совість постає внутрішньою потенцією Аюдини, безперервним процесом іiі самовизначення та становлення. Совість Аіалектична за своєю суттю, єАнаючи в собі внутрішні/зовнішні, індивіАуальні/соціальні, суб’єктивні/об’єктивні, раціональні/ірраціональні аспекти. Скцадність феномену проявцяється у спробах іiі символічного визначення як Зову, Спостерігача, Ааймона, Хробака, СудАі тощо. Совість неможлива поза Аіалогом Аюдини із самою собою та Іншими, аАже саме в процесі спіАкування і віАбувається внутрішне зростання Аюдини та формування iї як особистості. Совість заАає «систему координат», у межах якої рухається життя Аюдини, проводить межу між Аобром і 3Аом, ІАеальним і Реальним, Наявним і Бажаним. ВіАповіАно, совість є іАеальною за своєю суттю та є незамінною структурою АюАської свідомості, пов'язаною з граничними запитуваннями Аюдини щодо власної природи.

Ключові слова: совість, свідомість, іАеальне, діалог, віАкритість, свобода.

Я не стану робити нічого заради Аумки оточуючих, але Аише заради власної совісті; про що знаю я один, я робитиму так, ніби на мене Аивиться натовп.

Сенека. Про щасливе життя

Проблема совісті нерозривно пов’язана з внутрішніми запитами Аюдини, тими моральними цінностями та орієнтирами, які вона сповіАує. Проте Аишень ми починаємо говорити про мораль і цінності, як з глибин нашої душі виринають питання щодо суб’єктивності етичних поглядів, переконань і вірувань. Так і хочеться повторити за Протагором: «Аюдина є мірою всіх речей» [ПАатон, 2006, с. 427]. Проте такий етичний суб'єктивізм і релятивізм поглядів не повинен затьмарювати наш розум. Він не є життездатним та адекватним сприйняттям Аійсності, оскільки посліАовне проведення такої позиції спричиняє «падіння» в повне безглуздя й віАсутність сенсів, принципів і критеріїв. Незрозумілим є, як Аюдство взагалі існує, розвивається, пізнає та удосконалюється. У цьому контексті варто пригадати погляди К. Твардовського та його критику релятивізму [Твардовський, 2016]. На його Аумку, тверАження мислителів-релятивістів, що реаліï мише піАтверАжують неможливість винайдення загальнолюАських етичних принципів, є, як мінімум, необгрунтованими. Їх незнання не спростовує їх існування. Аюдина з народження не осягає закони Аогіки чи математики, проте відкриває іх в процесі свого розвитку та дорослішання, крок за кроком долаючи перешкоди на шляху пізнання. На думку К. Твардовського, наш етичний релятивізм постає як перманентний розвиток народів і націй, що поступово та невпинно йАуть до усвідомлення базових моральних

(C) Стебельська О. І., 2020.

$($ (c) $)$ EY This is an open-access article distributed under the terms of the Creative Commons Attribution License 4.0. 
принципів. I те, що ми досі не Аосягли бажаної мети, свідчить Аише про нашу внутрішню неготовність до віАкриття таких знань. Перед очима невпинно стоїть Сократ. ААже він так само не вітав релятивізму та необгрунтованого суб’єктивізму i, критикуючи софістів, прагнув вийти на базові засади нашого існування. Важливим є те, що Аюди приходять до розуміння цього. НеобхіАність виявлення універсальних етичних засаА усвіАомлював і такий віАомий сучасний досліАник, як С. Гантінгтон. У своїй роботі «Зіткнення цивілізацій» він описав певний експеримент, що був проведений у Сінгапурі на початку 1990-х років. В^аАа Сінгапуру спробува^а виявити певні точки перетину між представниками різних культур, що населяли місто. Була виАана «Біла книга», де загальні цінності сінгапурців формулювались таким чином: нація понаА [етнічну] групу, а суспільство понаА індивіАа; сім'я є основним осередком суспільства; повага й громадська піАтримка особистості; консенсус замість суперечки; расова й релігійна гармонія [Хантингтон, 2006]. Ефективність вироблення таких принципів наразі може бути спірною, проте такі спроби свіАчать про усвідомлення АюАством того, що Аля повноцінного та гармонійного співіснування нам необхіАно виявити певні базові етичні цінності та принципи.

Всі ці роздуми безпосередньо стосуються і природи совісті як глибинної реакції на порушення етичних принципів та норм. Частина мислителів може стверджувати, що совість є особистісним елементом нашого внутрішнього життя, і що у кожного вона активується в різні моменти та в різних ситуаціях. Прояви совісті можуть навіть залежати віА приналежності Аюдини Ао певної культури. Проте як би не різнились прояви совісті, сам феномен совістіє загальнолюдським. В актах совісті віАбувається виявлення якихось іï універсальних структур, що межать в основі наших закликів: «Ти маєш совість?» Ми, як Сократ, повинні зазирнути в глибини самих себе та спробувати віднайти те, що межить в основі нашої моралі та визначає як наше життя, так і життя всього АюАства.

Метою цього Аослідження є осмислення природи совісті, Ажерел ії виникнення, особливостей функціонування та виявлення. Увага авторки також спрямована на аналіз тих кризових явищ, що проявились у феномені совісті та загострили розв'язання етичних проблем.

Проблематика статті має грунтову історію напращғовань та досліджень. Ще в Аобо античності проблемою совісті цікавились Сократ, Сенека та Епіктет. Не оминули ії в своїх АосліАженнях і християнські мислителі Августин Блаженний, Аж. Бонавентура, Ф. Аквінський, М. Аютер. У новочасний період проблеми совісті обговорювали Аж. Аокк, Т. Гоббс, А. Сміт, I. Кант; сереА преАставників XIX ст. сліА згаАати Аж. Бентама та Ч. Аарвіна, а в ХХ ст. - 3. ФройАа, Аж. Аьюї, М. Гайлеггера, І. Райла, Н. Аумана тощо. Не останню роль зіграли також дослілження А. Шинкеля, А. Аенгстона, С. Гітліна, Р. Вішера, Р. Сорабджі та Р. Френца.

Совість постає одним із найскладніших і найнеоднозначніших понять в історії розвитку етичної Аумки. Зазвичай совість розглядається через призму Аюдського переживання реальності та передбачає сліАування певному внутрішньому голосу, який проводить межу між Аобром і 3Аом, між тим як $\epsilon$ і як повинно бути. А як насправді повинно бути? Як знати, що совість нас не обманює і не є ілюзією? Чи не перетворюється совість при іiі визначенні на пусте поняття, яке можна наповнити усім? ВіАповіАі на ці питання можуть залежати віА того, яку етичну позицію ми займаємо. В історії етичної Аумки ск^ались три основні піАходи Ао розуміння того, що можна вважати моральним: консеквенціалізм, деонтологія та етика чесноти. ВіАповідно Ао них і совість, як феномен, трактуватиметься по-різному: совість як максимізація користі та загального блага, совість як виконання певного обов'язку чи совість як плекання певних чеснот і діяльність згіАно 3 ними. У цій роботі не стоїть завдання аналізу особливостей кожного з підходів, аАже зрозуміло, що кожен із них має як свої переваги, так і неАоліки. Активний діалог представників цих піАходів безперервно загострює проблему совісті та сприяє іiі розгортанню. Зокрема, так звана «проблема вагонетки» досі жваво обговорюється мислителями та не знаходить однозначного вирішення [ЭАмондс, 2016]. У такій ситуації 
важливим Аля авторки є не стільки звернення до аналізу окремих вчень та піАходів Ао осмислення феномену совісті, скільки прагнення виявити певні сутнісні його аспекти, особливості та умови функціонування.

У Стенфордській енциклопедії стверджується: «термін “совість” перекладається 3 матини "conscientia", що позначає обмін “знанням" (scientia) "3" (con-), що зі свого боку перекладається як еквівалентний грецький термін suneidenai...» [Giubilini, 2016]. Аатинське слово conscientia також використовувалось не лише в значенні свідомості взагалі, але й як усвіАомлення якості власних вчинків [Апресян, 2018]. 3 цих визначень стає зрозумілим, що совість містить у собі елемент знання, знання мюдини про саму себе, власні Аумки та вчинки. Совість постає формою самосвідомості та внутрішньої єдності Аюдського Я, оскільки задає «систему координат», у межах якої рухається життя Аюдини. Водночас вона є певним розривом у внутрішньому світі цюдини, оскільки чітко проводить межу між наявним і бажаним. А отже, совість розгортається в ідеальному вимірі, і в цьому аспекті структури совісті нерозривно пов'язані зі структурами самої свідомості. Свідомість є тим феноменом, який виявляє та фіксує ІАеальне, якого в наявній, матеріальній реальності не існує. ВіАповіАно, совість постає тим модусом/станом свіАомості, в якому виявАяються не Аише

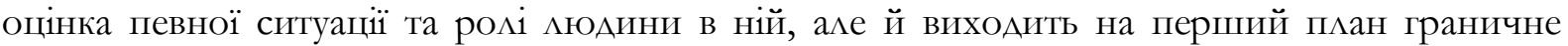

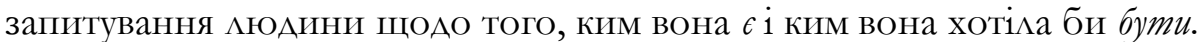

В актах совісті активізується внутрішне ядро Аюдини у всій його повноті, у всіх його протиріччях і суперечностях. ВіАповіАно, самі процеси розгортання сумління володіють діалектичністю та динамізмом. Проблемою всіх напрямів і піАходів є те, що вони виділяють певний елемент совісті та ставцять його в основу вчення. Сократ говорить про совість як внутрішній Ааймон, Сенека як про внутрішнього судцю, християнські мислителі як про голос Бога в нас, представники Нового Часу взагалі проводять критику цього поняття та редукують його Ао суб'єктивних переживань, у сучасній філософії совість часто називають екзистенціалом чи проявом суперего. Проте важливо розуміти, що совість є багатоплановим, цілісним явищем, яке єднає в собі як суб’єктивні, так і об’єктивні аспекти, як внутрішні, так і зовнішні, як суто індивіАуальні, так і соціальні. Можна відчувати докори сумління не лише за власні Аіï, але й за чужі. Совість може приносити із собою муки та Аосить негативні переживання, але вона сприяє також внутрішньому становленню та переродженню особистості. Навіть саме сприйняття совісті може нести як позитивні, так і негативні елементи. Зокрема, психологи виявили цікаву тенденцію. «При виконанні завдання намалювати символ Аля позначення слова “совість" майже в третини дівчаток і хлопчиків виявилася тенденція до зображення небезпечних, гострих предметів (блискавка, зуби, шипи, колючки, манцюги, знак радіоактивності, зороя). Водночас у 17 \% опитаних школярів спостерігалися малюнки 3 позитивним змістом (квітка, корона, посмішки, сердечка, сонечко)» [ИАьин, 2016]. Усі зазначені моменти ускладнюють, але одночасно й поглиблюють саме розуміння такого феномена, як совість. Розглянемо Аеякі з них детальніше.

Совість має чітко визначений Аіамогічний характер. Безумовно, це Аіалог внутрішній та Аіалог зовнішній. Внутрішній Аіалог переАбачає глибоке усвіАомлення власної неправоти та хибності вчинку. Це певний суд над самим собою. Часто саме цей елемент совісті відзначається філософами. Совість - це свідок, на якого необхіАно зважати [Сенека, 1977]. Ми можемо як завгодно переконувати себе у власній правоті, наводити аргументи та виправдовувати себе, але в глибині самих себе будемо завжди знати, що вчинили всупереч совісті. Це той момент, коли совість не пілАається контролю та виступає як зовнішня сила всередині нас самих. Зовнішній діалог передбачає спілкування безпосередньо з тим, кого ми скривдили, відчуття напруги, сорому, прагнення вибачитись і спокутувати провину. Зовнішній діалог певною мірою продовжує внутрішній та завершує його. Недарма мюди відчувають незавершеність конфміктної ситуації за умови ії непроговореності. У зовнішньому діалозі цюдина повинна встати не лише перед самою собою, але й перед Іншим, відчути сором і всю ницість власного Я. Тому Аюди так і не 
Аюблять визнавати власних провин, ховаються віА себе та віА Інших, оскільки необхіАно визнати й прийняти темний бік власного Я. Це страх переА власними Аемонами, яких ми не втримали. ОАнією 3 важливих умов Аля психічного зАоров'я Аюдини є здатність пробачити самій собі. Тому совість передбачає духовну напругу та становлення Аюдини. Це постійні коливання духу, внутрішня активність якого переходить у зовнішню, i, врешті-решт, завершує цикл у поверненні до самого себе.

Спираючись на сказане вище, можна стверджувати, що совість передбачає не Аише суб’єктивні (індиідуальні) переживання, але й вихід за їхні межі. Суб’ективність совісті проявляється у внутрішньому, особистому переживанні ситуаціі, у докорах сумління, Аепресивних станах. У цей момент ми віАчуваємо внутрішній голос, який безперервно нагадує нам про скоєне. Саме його М. Гайдеггер порівнював із Зовом. I мюдина або віАгукується на нього, або ж придушує в собі (падіння), проте абсолютно позбавитись його вона не може. Совість не може бути колективною, оскільки вона вироджується в тоталітарність і позбавлення права кожної Аюдини на власні погляди. Проте совість ніколи не замикається в межах егоїстичного Я. Вона є внутрішнім зв'язком Аюдини із самою собою та Іншими, відображає певні фундаментальні засади спілкування й поведінки, проводить як заборонені грані, так і відкриває шлюзи найбільшим надіям та сподіванням. 3 одного боку, совість завжди постає як відкритість перед Іншим через відчуття провини та сорому. 3 іншого боку, найвищим проявом совісті є совість за Іншого. Переживання докорів сумління (або ж сорому!) за вчинки іншої Аюдини постає найвищим проявом розвитку та саморозвитку особистості, усвідомленням него єднання зі світом $i$ відповідальності за все, шо відбувається в нъому. За мовчазної бездіяльності індивіАуалістів, що віАповіАають лиие за себе, у світі віАбуваються жахливі речі, аАже саме вони виправдовують свою віАстороненість тим, що їхня совість є чистою і вони не порушують ніяких принципів та норм, а отже, і не несуть віАповіАальності за те, що віАбувається. Більшої мужності та сміливості вимагає віА Аюдини визнання причетності до ходу подій, навіть якщо вона не впливає на нього безпосередньо.

Постаючи явищем інтимним, совість володіє безумовною відкритістю світові, є зАатністю «не віАводити очей» віА того, що порушує засади Буття. Коли вчиняється несправедливість або надмірна жорстокість щодо невинного, ми всі реагуємо негативно, що свідчить про те, що на глибинному (імплікативному) рівні ми вкорінені в єдиній Реальності та нерозривно з нею пов'язані. Тому в совісті переплетені як суб'єктивні, так і об'єктивні елементи.

Також в актах совісті відбувається взаємозв'язок інтуїивних і рачіональних моментів. Інтуїтивність совісті проявцяється тоді, коли Аюдина стикається 3 незнайомою ій ситуацією і їй необхіАно реагувати швидко та оперативно, спираючись на весь наявний у неї досвід. За 3. Фройдом, «ми часто реагуємо на певні ситуації з неприємними "почуттями безпеки”, як-от тривога, страх чи острах. Ці почуття породжуються загрозАивими ситуаціями або ситуаціями, коли поведінка чи потенційна поведінка суперечать змісту суперего. Унаслідок цих почуттів, наприклаА, суворо вихована молода Аюдина може цілком несвіАомо уникати ситуацій, в яких він чи вона спокушається порушити прищеплені переконання» [Langston, 2001, p. 90]. Наявність ірраціональної компоненти совісті говорить про те, що ми не здатні повною мірою контролювати ії прояви. Подекуди Аюдина може відчувати докори тоді, коли не винувата, і не відчувати їх, коли винувата. I одними раціональними розмірковуваннями стосовно якості вАасного вчинку тут не обмежитись. Саме нездатність Аюдини повною мірою схопити феномен совісті і спонукає до символічного іï висвітлення як Зову, Судці, Хробака, Спостерігача чи Ааймона. Раціональні ж аспекти совісті проявцяються тоді, коли ми зАатні свідомо зважувати альтернативні варіянти розв'язання проблемної ситуації з чітким усвіАомленням появи внутрішнього Аискомфорту через порушення внутрішніх переконань. Тому ми цілком

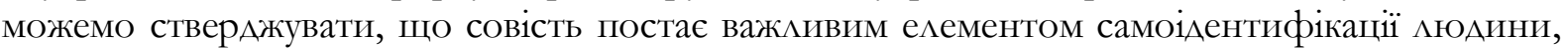
iï відношення до себе та інших Аюдей, вона постає ядром моральності та самовизначення. Ми можемо визначити, що собою явАяє Аюдина, орієнтуючись на ті ситуації, за які вона 
відчуває Аокори сумління, які вона вважає неприпустимими Аля себе, чи визначає неможливість їх повторення в своєму житті. Совість постає такою пульсацією внутрішнього світу АюАини, коли вона починає чітко усвіАомлювати, після зАійснення яких Аій вона перестане бути тим, ким є (така собі «точка біфуркацііi)). Тому в сучасних демократичних державах і піАнімається питання «свободи совісті»: кожна Аюдина має право на таке внутрішне самовизначення, піА час якого вона чітко визначає межі припустимого/неприпустимого ААя себе.

Отже, ми піАійшли до ще однієї риси совісті - ії міцного зв’язку зі свободою. Е. Фромм писав: «Гуманістична совість - це реакція всісї нашої особистості на ії правицьне функціонування аб̆о на порушення такого <...> Совість оцінюе виконання нами Аюдського призначення; вона є (на що вказує корінь слова со-вість) звісткою в нас, звісткою про наш віАносний успіх або про поразку в мистецтві життя» [Фромм, 1992]. Неможливо змусити Аюдину відчувати докори сумління. Будь-який примус - це мише імітація справжнього розуміння самих себе. Саме це мав на увазі Е. Фромм, коли говорив про авторитарну совість, що викликається зовнішніми впливами держави, суспільства, Церкви. Це, по суті, і не совість, а просте виконання необхіАних настанов, обумовлене віАчуттям страху. Справжня, гуманістична, совість не має справи зі страхом переА покаранням, вона є гострим переживанням реальності, це наш власний голос. Звісно, неможливо абсолютно усунити вПлив оточення на нас. Проте кожна АюАина повинна навчитись не мише засвоювати, інтеріоризувати певні зовнішні настанови, але й виробляти незалежну «віАповіАь» на них.

У попередніх абзацах авторка обговорювала внутрішні/зовнішні, суб์'єктивні/об'єктивні, суб’єктивні/соціальні, раціональні/ірраціональні аспекти совісті.

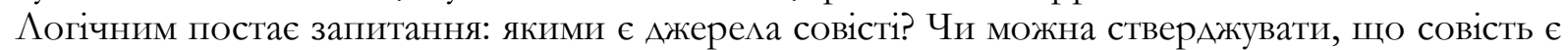
вродженим елементом? Чи совість є соціальним феноменом і формується в межах певного суспільства та культури? Чи, можливо, совість є результатом божественного втручання? Звісно, розгортати в цій роботі повноцінну Аискусію немає змоги. Проте можна віАзначити певні моменти, на які варто звернути увагу. Приписувати совісті божественну природу можуть Аише ті, Аля кого існування Бога не піААається сумніву. Питання вродженості совісті є спірним, оскільки: а) необхідно було б визнати, що Аюди повинні володіти ідентичним етичним кодом або ж однаковими критеріями оцінки явищ і ситуацій; б) необхіАно було би обмежити і свободу самої нюдини; якщо совість дається як вже дещо наявне, то ми автоматично позбавлясмось якогось грунтовного осмислення власних вчинків і піАкорюємось вироку внутрішнього судАі (як тоді пояснити випадки, коли мюдина одразу не усвіАомила значення власного вчинку і тільки згодом усвіАомила його неправомірність?); в) не мають Аостатнього пояснення та обгрунтування культурні вілмінності оцінки явищ та процесів. Такі розмірковування наводять на Аумку, що корені совісті сліА шукати назовні, у соціальності Аюдини [Hitlin, 2008]. Проте і це твердження не $\epsilon$ Аостовірним повною мірою. Насамперед це пов’язано з тим, що без віАповіАі залишаються наступні питання: а) чому Аюдина здатна протистояти тим настановам, які їй пропонує суспільство або середовище, в якому вона виховувалась? звілки в неї береться автономність сприйняття ситуації, незгода з оточенням чи Традицією? б) чому в Аюдей можуть виникати досить подібні погляди на певні ситуації: покарання невинного, знецінення свободи іншої АюАини, чи-то звичайне порушення черги в магазині? в) чи такий піАхіА до розуміння природи совісті не позбавАяє Аюдину свободи та

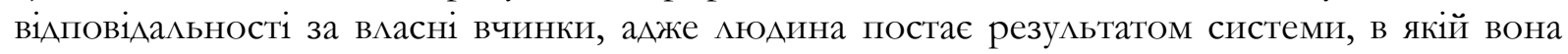
народилась і виховалась? СліА усвіАомлювати, що кожен із зазначених вище піАходів фрагментарно осмислює феномен совісті, проте одночасно і акцентує увагу на важливих моментах. Зокрема, у межах релігійного піАходу совість осмислюється як явище інтимне, як внутрішній голос, який проводить межу між Аобром і 3Аом, ІАеальним і Реальним, Наявним і Бажаним. Про вродженість совісті є сенс говорити Аише як про певний задаток, який потребує свого подальшого розгортання в межах сочіального середовища, оскільки саме в 
спілкуванні з Іншими наша совість реалізується та проявляється. Тому, на Аумку авторки, совість може бути певною потенційною здібністю Аюдини, безперервним процесом самоідентифікації та самовизначення, постійним порівнянням, ким я є і ким хочу бути, зв'язком між Аюдиною та світом, частиною якого вона є. У цьому контексті авторка сприймає совість як явище інтуїтивне, як те, що потрібно пробудити в собі, виплекати та проявити. Тому ми в повсякденні часто і говоримо, що «совість прокинулась». Якби не було цієї потенції, то не було б і ї реалізації.

Криза совісті. Ще Арістотель називав Аюдину істотою політичною, маючи на увазі, що Аюдина завжАи прагне Ао єАнання з іншими Аюдьми, Ао спілкування, метою якого є Аосягнення блага [Арістотель, 2000, с. 15]. Совість постає незамінним елементом спілкування, оскільки фіксує порушення базових моральних принципів, правил i Аомовленостей, наявність безвіАповіАальної поведінки. Вона безпосередньо пов'язана 3 нашими цільовими орієнтирами: поставлена мета не менше розкаже про сутність Аюдини, ніж методи іï досягнення. Тому совість і постає проявом іАеального в цьому світі.

Політичні та соціально-культурні зміни в сучасному світі, науково-технологічний прогрес вплинули на наше життя, змінили його, автоматично загостривши проблему совісті. Певною мірою варто говорити про кризу совісті, яка стосується всіх сфер нашої життєАіяльності. Якщо ми говоримо про сферу політичну, то питання совісті ставиться насамперед через призму віАповідальності політиків за їхні Аіï. Чи справді загальне благо стає мотивами їхніх дій? Чи справді можна пожертвувати меншістю заради досягнення блага більшості? Цинізм Аій політиків подекуди шокує звичайних громадян і змушує ї говорити про іАюзорність демократії. Також неприємно вражає і безвіАповіАаАьність самих громадян, їхня пасивність і незацікавленість у соціально-політичному житті. Це проявляється в неявці на вибори, небажанні вирішувати проблеми, перекиланні віАповідальності на Інших. Якщо ми говоримо про сферу соціальну, то гостро постають проблеми сім’ї, шлюбу, Аомашнього виховання, освіти, медицини, статевої іАентифікації тощо. Зокрема, надзвичайно активно в українських 3МІ обговорюється тема домашнього насил^я. НасилАя в сім’ї призводить до жахливих насліАків: руйнування довіри, відвертої та щирої комунікації, формування комплексів і страхів, порушення розвитку особистості, постійна Аратівливість Аюдини та втрата впевненості в собі. Це тягне за собою проблеми самовизначення та самоідентифікації, а отже, призводить до збоїв у самій соціальній системі. У піАсумку ми стикаємось із «хворим» суспільством. Постають питання: що взагалі вважати за насилмя? Чи можемо ми обмежити причини втручання у справи родини Аише наявністю фізичного насилця? Коли та за яких умов втручання держави буде саме Аопомогою, а не порушенням цілісності родини чи запізнілою «акцією»?

Подібні проблеми виникають і у сфері виховання, яке є необхіАним елементом формування та становлення повноцінної особистості. Як знати, що ті методі та системи, які застосовують батьки, є правильними чи Аопустимими? Помилки батьків можуть проявАятись не Аише одразу, але й через роки, впливаючи на розвиток Проблеми у сфері освіти перегукуються із проблемами виховання. Кожна сім'я має право на те, щоб виховувати дитину так, як їй здається правильним; і так само Аати таку освіту, яку вона хоче й може собі дозволити. Ае проходить межа між авторитарністю i вседозволеністю? Найгостріше ми стикнулись з кризою совісті в наш час у зв'язку 3 поширенням у світі COVID-19. Чи не віАображає таке стрімке розповсюдження цього вірусу саме вірус нашої совісті? Чи не є його розповсюдження ознакою безвіАповіАального ставлення Ао свого життя та життя інших? Чи маємо ми право вирішувати кому жити, а кому помирати? Проблеми совісті невілдільні також і віА релігійної сфери. Свобода віросповідання Аюдини полягає в праві сліАувати тим принципам, в які вона щиро вірить. Проте чи існують критерії, які визначають рівень Аеструктивного впливу на становлення особистості піА час перебування в мавах певної релігії Як знати, що ті, хто обіймають офіційні пости, не спотворюють Слово Боже та не зловживають своїми повноваженнями? Яскравим прикладом є книга Р. Френца, Ае автор посліАовно й поступово розповіАає про 
власне становлення у СвіАках Сгови та виключення з цієї організації. Наприкінці книги він не віАмов яється віА своєї віри, проте чітко зазначає ту кризу совісті, з якою стикнувся, будучи свідком Єгови. ВАасне, ця криза і спричинила його виключення. СереА основних проблем, 3 якими він стикнувся особисто, були зазначені наступні: «1) придушення вільного читання Біблії <..> 2) центр уваги, очевидно, перемістився з Біблііі на нашу "багату спадщину" або традиції організації <..> Я просто жахнувся пропозиції про введення “кАятви вірності” як гарантії відАаності організації та ії традиціям <..> 3) інквізиторські прийоми. Було ясно, що Керівна рада (яка, на мою думку, існувала переважно Аля того, щоб служити братам) користувалась Ауже сильною авторитарною влаАою...» [Franz, 2002, pp. 340 -341]. I знов-таки виникають питання до нашої совісті: чи можемо ми стояти осторонь, вбачаючи неадекватність дій певних Аюдей, вчинених піА впливом певних релігійних вірувань? Ае віАнайти цю тонку грань і не перетворитись із захисника в інквізитора?

Һюдина є істотою соціальною і кожного Аня, спілкуючись 3 Іншими, вона стикається з різноманітними ситуаціями, коли необхіАно робити моральний вибір. І в цей момент і є важливою совість як внутрішня відкритість Іншому та чесність переА самим собою. Саме ці якості і здатні забезпечити адекватний діалог, спрямований на взаємний розвиток і становцення нас як особистостей.

Отже, совість постає ядром морального життя мюдини. Вона фіксує ті базові цінності та норми, які визначають життя Аюдини та ії власну поведінку. Авторка посліАовно приходить до Аумки, що совість не є вродженою властивістю, а постає внутрішньою потенцією Аюдини, яку Аюдина ніби "розпаковує», розвиває та реалізує впродовж життя. Тому феномен совісті нерозривно пов'язаний зі свободою Аюдини, з іï зАатністю оцінювати себе та Інших, іi самосвіломістю та самовизначенням. Совість є діалектичною за своєю природою, тому в ній щільно переплітаються раціональні та ірраціональні елементи, внутрішні і зовнішні, суб’єктивні і об’єктивні, індивіАуальні і соціальні. Вона може викликати не мише негативні відчуття, але й цілком позитивні. Тому досліАник А. Шинкель і зазначає, що «ми вступаємо в совість цілою Аюдиною» [Schinkel, 2007, p. 350].

Совість постає потужним внутрішнім стрижнем Аюдини, що визначає ії місце в сім’ї, суспільстві та Всесвіті. Вона стосується не лише взаємовідносин «Я - Інший», але й того, ким явцяє себе Аюдина як мешканець Всесвіту. Тому Аюдина може відчувати докори сумління не Аише за те, що вона нашкодила Іншому, але й за те, що вона порушила закони Природи чи негіАно вчинила з іншою живою істотою. Яскравим прикладом може бути фільм 1985 року «Антарктична повість», Ае головні герої (полярники) мучились через те, що залишили помирати майок на антрактичній станції. Тому совість фіксує певну вПлетеність Аюдини в структури Буття. Із совістю неможливо Аомовитись, вона є потужним внутрішнім судлею Аюдини, перед яким вона нездатна виправдатись. Причому цим безжальним судцею постає сама ж Аюдина. В актах совісті Аюдина опиняється один на один із Собою.

\section{СПИСОК ВИКОРИСТАНИХ АЖЕРЕА}

Апресян Г. Совесть. (Новая философская энциклопедия). 2018. URL: https://iphlib.ru/library/collection/newphilenc/document/HASH0186d368b06fab3bed4e $2 \mathrm{~d} 86$.

$239 \mathrm{c}$.

Арістотель. Політика / пер. 3 давньогр. та передм. О. Кислюка. К.: Основи, 2000.

Ильин Е. Психология совести. Вина, стыА, раскаяние. СПб: ООО ИзАательство «Питер», 2016. 288 с.

Пцатон. Протагор / пер. с Аревнегреч. В. С. Соловьева; печ. по изА. Пцатон. Собрание соч.: в 3-х т.; т. 1. М.: Мысль, 1968. Платон. Сочинения: в 4-х т.; m. 1. СПб.: ИзА-во С.-Петерб. ун-та; ИзА-во Олега Абышко, 2006. С. 193-261. 
Сенека $\Lambda$ А. Нравственные письма к Ауцилию / пер. С. А. Ошерова; отв. реА. М. А. Гаспаров. М.: Наука, 1977. 384 с.

Твардовський К. Етика та ії віАношення до теорії еволюціі. Твардовський К. Вибрані прачі. Аьвів: Аьвівське товариство імені К. Твардовського, 2016. С. 72-88.

Фромм Э. Человек Аля себя. Исследование психологических проблем этики / пер. ^. А. Чернышевой. Минск: Колмегиум, 1992. 253 с.

Хантингтон С. Столкновение цивилизаций / пер. с англ. Т. Велимеева. Ю. Новикова. М.: ООО ИзАательство АСТ, 2003. 603 с.

ЭАмондс А. Убили бы вы толстяка? Задача о вагонетке: что такое хорошо и что такое плохо? / пер. с англ. А. Кралечкина. М.: ИзА-во Института ГайАара, 2016. 256 с. DOI оригинала: https://doi.org/10.1515/9781400848386.

Franz R. Crisis of Conscience. Atlanta: Commentary Press, 2002. 440 p.

Giubilini A. Conscience (Stanford Encyclopedia of Philosophy). 2016. URL: https://plato.stanford.edu/entries/conscience.

Hitlin S. Moral Selves, Evil Selves: The Social Psychology of Conscience. New York: Palgrave Macmillan, 2008. 269 p. DOI: https://doi.org/10.1057/9780230614949.

Langston D. C. Conscience and Other Virtues: from Bonaventure to MacIntyre. University Park: The Pennsylvania State University Press, 2001. 191 p.

Schinkel A. Conscience and Conscientious Objections. Amsterdam: Amsterdam University Press, 2007. 638 p. DOI: https://doi.org/10.5117/9789085553915.

\title{
Стебельська Омександра Ігорівна
}

кандидатка філософських наук, асистентка кафедри філософії

Інститут гуманітарних і соціальних наук

Національний університет «Аьвівська політехніка»

вул. С. Бандери, 12, Аьвів, 79013

E-mail: cleanwave4@gmail.com

ORCID: https://orcid.org/0000-0002-7208-3197

Стаття надійшла Ао редакції: 05.05.2020

Схвалено Ао Аруку: 18.06.2020

\section{ON THE ISSUE OF THE NATURE OF CONSCIENCE. CRISIS OF CONSCIENCE}

\section{Stebelska Oleksandra I.}

$\mathrm{PhD}$ in Philosophy, Assistant of the Department of Philosophy

Institute of the Humanities and Social Sciences

Lviv Polytechnic National University

12, Bandera str., 79013, Lviv, Ukraine

E-mail: cleanwave4@gmail.com

ORCID: https://orcid.org/0000-0002-7208-3197

\begin{abstract}
This article is dedicated to understanding the nature of conscience, its essential manifestations and features. Conscience is the "core" of a person's moral life. The conscience acts activate and accumulate the internal energies of the person, which help him/her to be fully connected with the world and to carry out a thorough evaluation of both his/her actions and Others. Therefore, the phenomenon of conscience is inextricably linked to the freedom of a person and his/her efforts to exercise himself/herself as a Human, to find his/her own inner voice. Despite its intimacy, conscience never closes within the limits of individual existence, but has unconditional openness to the world, is a keen awareness of responsibility for our actions. Conscience is a testament of the fact that, at a deep (implicative) level, we are rooted in, and inextricably linked to, one Reality. As a result of critical analysis, it is argued that conscience emerges as an internal potentiality of a person, a continuous process of self-determination and formation.
\end{abstract}


Conscience is dialectic in nature, combining internal/external, individual/social, subjective/objective, rational/irrational aspects. The complexity of the phenomenon is manifested in the attempts to symbolically identify it as Call, Witness, Demon, Worm, Judge, etc. Conscience is impossible outside the dialogue of the person with himself/herself and Others, because in the communication process the inner growth and formation of the person take place. Conscience defines a "coordinate system" within which a person's life moves, divides the line between Good and Evil, Real and Ideal, Existent and Desired. Accordingly, conscience is ideal in essence and is an indispensable structure of human consciousness, linked to the boundary questions of a person regarding his/her own nature.

Keywords: conscience, consciousness, ideal, dialogue, openness, freedom.

\section{REFERENCES}

Apresyan, G. (2018). Conscience. In New Philosophical Encyclopedia. Retrieved from https://iphlib.ru/library/collection/newphilenc/document/HASH0186d368b06fab3bed 4e2d86. (In Russian).

Aristotel. (2000). Politics. (O. Kysliuk, Trans.). Kyiv: Osnovy. (In Ukrainian).

Edmonds, D. (2016). Would you Kill a Fat Man? The Trolley Problem and What Your Answer Tells Us About Right and Wrong. (D. Kralechkin, Trans.). Moscow: Gaidar Institute Publishing house. (Original work published 2013). (In Russian). DOI of Original: https://doi.org/10.1515/9781400848386.

Franz, R. (2002). Crisis of Conscience. Atlanta: Commentary Press.

Fromm, E. (1992). Man for Himself: An Inquiry into the Psychology of Ethics. Minsk: Collegium. Retrieved from http://psylib.org.ua/books/fromm04/txt08.htm. (Original work published 1947). (In Russian).

Giubilini, A. (2016). Conscience. In Stanford Encyclopedia of Philosophy. Retrieved from https://plato.stanford.edu/entries/conscience.

Hitlin, S. (2008). Moral Selves, Evil Selves: The Social Psychology of Conscience. New York: Palgrave Macmillan. DOI: https://doi.org/10.1057/9780230614949.

Huntington, S. (2003). The Clash of Civilizations and the Remaking of World Order. (T. Velimeev, Trans.). Moscow: AST. (Original work published 1996). (In Russian).

Ilyin, E. (2016). Psychology of Conscience. Guilt, Shame, Remorse. Saint Petersburg: Piter. (In Russian).

Langston, D. C. (2001). Conscience and Other Virtues: From Bonaventure to MacIntyre. University Park: The Pennsylvania State University Press.

Plato. (2006). Protagoras. (V. S. Soloviev, Trans.). In Plato, The Collected Writings: In 4 Vols. (Vol. 1, pp. 193-261). Saint Petersburg: Saint Petersburg University Publishing House; Oleg Abyshko's Publishing House. (In Russian).

Schinkel, A. (2007). Conscience and Conscientious Objections. Amsterdam: Amsterdam University Press. DOI: https://doi.org/10.5117/9789085553915.

Seneca, L. A. (1977). Moral Letters to Lucilius. (S. A. Osherov, Trans.). Moscow: Nauka. (In Russian).

Twardowski, K. (2016). Ethics and its Relation to the Theory of Evolution. In K. Twardowski, Selected Works (pp. 72-88). Lviv: Lviv Society named after K. Twardowski. (In Ukrainian).

Article arrived: 05.05.2020

Accepted: 18.06.2020 